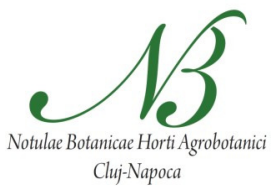

\title{
Nutritional and Nutraceutical Components of Commercial Eggplant Types Grown in Sinaloa, Mexico
}

\section{Guillermo NIÑO-MEDINA ${ }^{1,2}$, Dolores MUY-RANGEL ${ }^{1 *}$, Alfonso GARDEA-BÉJAR ${ }^{3}$, Gustavo GONZÁLEZ-AGUILAR ${ }^{3}$, Basilio HEREDIA ${ }^{1}$, Manuel BÁEZ-SAÑUDO ${ }^{1}$, Jorge SILLER-CEPEDA ${ }^{1}$, Rosabel VÉLEZ DE LA ROCHA ${ }^{1}$}

\author{
${ }^{I}$ Centro de Investigación en Alimentación y Desarrollo (CLAD) A.C., Unidad Culiacán, Carretera Culiacán a El Dorado, km 5.5, \\ C.P.80110, Culiacán, Sinaloa, Mexico;mdmuy@ciad.mx ("correspondingauthor); \\ jbheredia@ciad.mx;manuel.baez@ciad.edu.mx; jhsiller@ciad.mx;rosabel@ciad.edu.mx \\ ${ }^{2}$ Universidad Autónoma de Nuevo León, Facultad de Agronomía, Francisco Villa S/N, C.P. 66050, \\ Col.Ex-Hacienda El Canadá, Escobedo, Nuevo León, Mexico (present address); guillermo.ninomd@uanl.edu.mx \\ ${ }^{3}$ Centro de Investigación en Alimentación y Desarrollo, (CLAD) A.C., Unidad Hermosillo, Carretera a La Victoria km 0.6, \\ C.P.83304,Hermosillo,Sonora, Mexico; gardea@ciad.mx; gustavo@ciad.mx
}

\begin{abstract}
The nutrimental composition and main nutraceutical components were determined in Chinese, Philippine, American, Hindu and Thai eggplant (Solanum melongena L.) types grown in Sinaloa, Mexico. Thai type showed the highest amount of protein $(0.90 \%)$, crude $(1.54 \%)$ and dietary $(3.93 \%)$ fibre and the highest concentrations of total soluble phenolics (2049 $\left.\mathrm{mgCAE} 100 \mathrm{~g}^{-1}\right)$ and chlorogenic acid $\left(1700 \mathrm{mg}^{100 \mathrm{~g}^{-1}}\right)$. Hindu type obtained the highest content of the minerals potassium

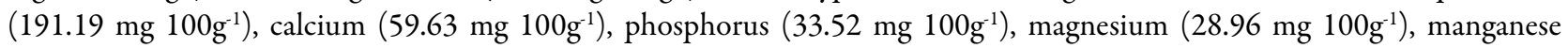
$\left(0.44 \mathrm{mg}_{100 \mathrm{~g}^{-1}}\right)$, zinc $\left(0.78 \mathrm{mg}^{100 \mathrm{~g}^{-1}}\right)$, in addition this eggplant type showed the highest levels of ascorbic acid $\left(22 \mathrm{mg} 100 \mathrm{~g}^{-1}\right)$. Philippine type showed the highest concentration in anthocyanins $\left(161.10 \mathrm{mgC}_{3} \mathrm{GE}_{100 \mathrm{~g}^{-1}}\right)$ and the highest levels of radical scavenging activity in DPPH $\left(92.50 \%\right.$ of inhibition) and ORAC $\left(538.90 \mu\right.$ molTE $\left.\mathrm{g}^{-1}\right)$. Nutrient components with functional properties like biologically essential minerals, dietary fibre, ascorbic acid (vitamin C) and soluble phenols were found in higher amounts in the five eggplant types analyzed, as compared with reports from other parts in the world available in the literature.
\end{abstract}

Keywords: antioxidant capacity, ascorbic acid (Vitamin C), chlorogenic acid, mineral content, proximate composition, Solanum melongena L., total soluble phenols

\section{Introduction}

The eggplant (Solanum melongena L.) also known as aubergine, guinea squash or brinjal, is an economically important vegetable crop in the tropics and subtropics. Eggplant cultivars produce fruits with a wide diversity of shapes, sizes and colours (Kashyap et al., 2003; Kantharajah and Golegaonkar, 2004). Sinaloa, in northwest Mexico, is the major eggplant producer in the country, growing an average of eight eggplant types, out of which American type is the most widely grown. Eggplants have an important nutritional value due to its composition, which includes minerals like potassium, calcium, sodium and iron (Mohamed et al., 2003; Raigón et al., 2008) as well as dietary fibre (USDA, 2014; Sanchez-Castillo et al., 1999). Fruits and vegetables are the main dietary sources of phenolic compounds for humans, with phenolic acids and flavonoids being the most abundant (Scalbert and Williamson, 2000; Manach et al., 2004). Eggplant fruits have shown high hydrophilic oxygen radical absorbance capacity (ORAC) (Cao et al., 1996), which has been correlated to phenolic compounds presence, including delphinidin as a major component in peel (Wu et al., 2006; Koponen et al., 2007) and chlorogenic acid in flesh (Winter and Hermann, 1986; Whitaker and Stommel, 2003). Other studies of the main phenolics reported in eggplants, showed that they are well metabolized and absorbed (Olthof et al., 2001; Olthof et al., 2003), also they show a good antioxidant capacity (Noda et al., 2000; Hanson et al., 2006). The aim of this work was to characterise and compare the proximal composition, mineral content and antioxidant bioactive compounds of eggplant types grown in Sinaloa, Mexico. 


\section{Materials and methods}

\section{Samplepreparation}

Eggplant fruits from the representative types of Chinese, Philippine, American Hindu, and Thai were used in this work (Fig. 1). Fruit smples of each eggplant type were harvested at commercial ripeness stage from a local farm $\left(24^{\circ} 40^{\prime} 50^{\prime \prime} \mathrm{N}\right.$ and $\left.107^{\circ} 30^{\prime} 18^{\prime \prime} \mathrm{W}\right)$, washed and sorted by colour and size and divided into two groups. The first group was used fresh for proximate and mineral analysis, while the second group was freeze dried and stored at $-80{ }^{\circ} \mathrm{C}$, for further evaluations of ascorbic acid, chlorogenic acid and total phenolics.
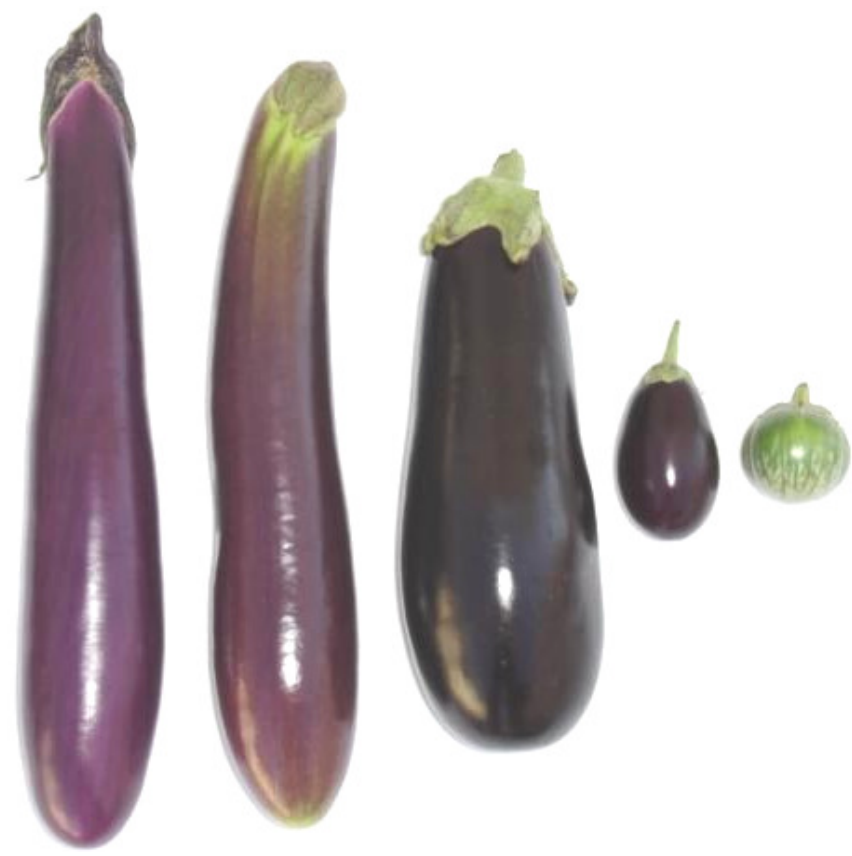

Fig. 1. Phenotypic differences among eggplant types (from left to right: Chinese, Philippine, American, Hindu, and Thai)

\section{Proximate composition}

Moisture, ash, protein ( $\mathrm{N} \times 6.25)$, crude fibre, fat and carbohydrates (by difference) contents were determined according to AOAC methods (AOAC, 1998). Total dietary fibre was evaluated by the Megazyme total dietary fibre assay procedure, which is based on the AOAC 991.43 method (AOAC, 1998).

\section{Mineral content}

Mineral analysis was done based on AOAC methods (AOAC, 1998). Potassium (K), sodium (Na), calcium (Ca), magnesium $(\mathrm{Mg})$, iron $(\mathrm{Fe})$, zinc $(\mathrm{Zn})$, copper $(\mathrm{Cu})$ and manganese $(\mathrm{Mn})$ were determined by atomic absorption spectroscopy using a Varian SpectrAA 220. Phosphorus (P) was determined colorimetrically at $650 \mathrm{~nm}$ in a Varian Cary E1 $\mathrm{UV}-\mathrm{V}$ is spectrophotometer.

\section{Ascorbic acid (Vitamin C)}

Ascorbic acid extraction was done according to Özgür and Sungur (1995) with the following modifications; $100 \mathrm{mg}$ of freeze dried sample were mixed with $5 \mathrm{~mL}$ of extraction solution at $5{ }^{\circ} \mathrm{C}(3 \%$ metaphosphoric acid, $8 \%$ acetic acid, $1 \mathrm{mM}$ EDTA). The extract was filtered through a Whatman No. 1 filter paper and passed through $45 \mu \mathrm{m}$ nylon syringe filter. Ascorbic acid was quantified according to Doner and Hicks (1981) using a Varian Pro Star 330 photodiode array detector HPLC system and a Varian Bondesil $\mathrm{NH}_{2}$ column $(250 \times 4.6 \mathrm{~mm})$. A 3:1 solution of acetonitrile and potassium phosphate $(0.05 \mathrm{M})$ was used as the mobile phase at $1.5 \mathrm{~mL}$ $\min ^{-1}$. Detection was measured at $268 \mathrm{~nm}$ with a retention time at $2.1 \mathrm{~min}$. Standard solutions of $0,0.05,0.10,0.15$ and $0.20 \mathrm{mg} \mathrm{mL}^{-1}$ of ascorbic acid were prepared for calibration. Results were expressed in milligram per 100 gram of eggplant on a fresh basis.

\section{Soluble phenolic compounds}

Phenolics extract was obtained according to Whitaker and Stommel (2003) with these modifications; $200 \mathrm{mg}$ of freeze dried sample were mixed with $10 \mathrm{~mL}$ of methanol containing $0.5 \%$ butylated hydroxytoluene (BHT) and sonicated at room temperature for $15 \mathrm{~min}$ in an ultrasonic bath (Fisher Scientific Model FS60). After centrifugation at $16,000 \mathrm{~g}$, supernatant was recovered and re-extracted twice with $10 \mathrm{~mL}$ of solvent. Extracts were combined, filtered through Whatman No. 4 paper and passed through $45 \mu \mathrm{m}$ PTFE syringe filter.

\section{Total solublephenolics}

Total soluble phenolics were determined using $2 \mathrm{~mL}$ aliquots of phenolics extract; the solvent was evaporated at 35 ${ }^{\circ} \mathrm{C}$ by flushing dry $\mathrm{N}_{2}$ and the residue dissolved in $10 \mathrm{~mL}$ of methanol. Total phenols determination was done according to spectrophotometric method based on the colorimetric reaction of the Folin-Ciocalteu reagent (Chun and Kim 2004). Absorbance was measured at $750 \mathrm{~nm}$ in a Varian Cary E1 UVVis spectrophotometer (Varian, USA). Results were expressed in $\mathrm{mg}$ chlorogenic acid equivalents per 100 grams (mg CAE $100 \mathrm{~g}^{-1}$ ) of eggplant tissue in a dry basis, using a calibration curve with a standard solution of $0,0.25,0.50,0.75$ and $1.00 \mathrm{mg} \mathrm{mL}^{-1}$ of chlorogenic acid.

\section{Chlorogenic acid}

For chlorogenic acid determination, a $1.5 \mathrm{~mL}$ aliquot of phenolics extract was taken, solvent was evaporated at $35^{\circ} \mathrm{C}$ by flushing dry $\mathrm{N}_{2}$ and dissolved in $2 \mathrm{mM}$ phosphoric acid in methanol-water (1:1); HPLC analysis was done using binary mobile phase gradient of methanol in $1 \mathrm{mM}$ aqueous phosphoric acid and a Phenomenex Luna $\mathrm{C}_{18}$ column $(250 \mathrm{x}$ $4.6 \mathrm{~mm}$ ) in a Varian Pro Star 330 photodiode array detector HPLC system (Whitaker and Stommel, 2003). Detection was done at $325 \mathrm{~nm}$ with a retention time in $19.7 \mathrm{~min}$. Standard solutions of $0,0.25,0.50,0.75$ and $1.00 \mathrm{mg} \mathrm{mL}^{-1}$ of chlorogenic acid were prepared for calibration curve. Results were expressed in milligram per 100 gram of eggplant tissue on a dry basis. The percentage of chlorogenic acid in comparison with total phenols was calculated, as well.

\section{Total anthocyanins}

Total anthocyanin was determined using a spectrophotometric method adapted from Abdel-Aal and Hucl (1999). An eggplant sample of $0.5 \mathrm{~g}$ was homogenized with $10 \mathrm{~mL}$ of chilled, acidified methanol ( $95 \%$ methanol and $1 \mathrm{~N} \mathrm{HCl} \mathrm{85:15,v/v).} \mathrm{The} \mathrm{tube} \mathrm{was} \mathrm{flushed} \mathrm{with} \mathrm{nitrogen} \mathrm{gas,}$ 
agitated for $30 \mathrm{~min}$, and centrifuged at $3000 \mathrm{~g}$ for $10 \mathrm{~min}$, and the supernatant was collected. Solution absorbance was measured immediately at 535 and $700 \mathrm{~nm}$. Anthocyanin content was calculated as the concentration of total anthocyanin, expressed as $\mathrm{mg}$ of cyanidin-3-glucoside equivalents per $100 \mathrm{~g}$ of sample $\left(\mathrm{mgC}_{3} \mathrm{GE} 100 \mathrm{~g}^{-1}\right)$. The molar absorptivity and molecular weight of cyanidin-3-glucoside are $25965 / \mathrm{cm} / \mathrm{M}$ and $449.2 \mathrm{~g}$ per mole, respectively.

\section{DPPH antioxidant capacity}

Eggplant samples $(5 \mathrm{~g})$ were homogenized with $20 \mathrm{~mL}$ methanol, until reaching uniform consistency and incubated overnight at $4{ }^{\circ} \mathrm{C}$ (Heredia and Cisneros-Zeballos, 2009). Homogenates were centrifuged at $29,000 \mathrm{~g}$ for $15 \mathrm{~min}$ at $4^{\circ} \mathrm{C}$. Sample aliquots of $150 \mu \mathrm{L}$ were taken from the clear supernatants and then diluted with a 2,850 $\mu \mathrm{L}$ DPPH solution, previously prepared with methanol, until reaching 1.1 units of absorbance at $515 \mathrm{~nm}$. Methanol was used as control and to zero the spectrophotometer (Agilent Technologies, Mexico). Further readings of all samples were done at $515 \mathrm{~nm}$. The mixture reaction was allowed to react in a shaker until no significant decrease in absorbance was obtained, compared to the methanol-based control for antioxidant activity. The decrease in absorbance was obtained and the results for antioxidant activity were expressed as \% radical scavenging activity, calculated as follows: \% Radical scavenging activity = (absorbance $_{\text {control-absorbance }}$ smple/absorbance control $^{*}$ 100. Percentage of radical scavenging activity was plotted against the corresponding concentration of the extract to obtain the $\mathrm{IC}_{50}$ value, which is defined as the amount of antioxidant material required to scavenge $50 \%$ of free radical in the assay system. $\mathrm{IC}_{50}$ values are inversely proportional to antioxidant activity.

\section{ORAC antioxidant capacity}

The eggplant methanolic extract sample was also used for ORAC measurements against peroxyl radicals (Huang et al., 2002; Prior et al., 2003). Sample extracts, Trolox standard (40 $\mu \mathrm{M})$ and reagents were dissolved in $75 \mathrm{mM}$ potassium phosphate buffer, pH 7.4, and assayed on a Bio-Tek Synergy HT plate reader with automatic using 96-well plates. The fluorescein stock solution (FLs) was prepared with $0.1125 \mathrm{~g}$ of fluorescein (FL) in $50 \mathrm{~mL}$ of the buffer. Next, $100 \mu \mathrm{L}$ of FLs was diluted in $10 \mathrm{~mL}$ of the buffer (FL2). A third FL solution (FL3) was prepared by taking $400 \mu \mathrm{L}$ of FL2 to $25 \mathrm{~mL}$. The assay was performed at $37^{\circ} \mathrm{C}$. Samples were loaded into the 96- well plate $(25 \mu \mathrm{L})$, with each row containing different samples or dilutions. Two columns were loaded with $25 \mu \mathrm{L}$ of Trolox and the buffer (blank), respectively. At $15 \mathrm{~min}$, the AAPH peroxyl radical solution (2,2'-azobis 2-amidinopropane) dihydrochloride was prepared right with the incubated buffer. The FL3 and AAPH solutions were then transferred into the incubated autoinjector plastic containers. The plate reader was configured to inject $200 \mu \mathrm{L}$ of FL3, the shaking plate was set at medium intensity for $3 \mathrm{~s}$, injecting $75 \mu \mathrm{L}$ of AAPH solution, and taking readings for $50 \mathrm{~min}$ every 1:27 min (35 cycles) without shaking during readings. The reading mode was fluorescence kinetic with injection (Ex/Em: 485/528). Data were recorded with the GEN-5 software and exported into Excel. Relative fluorescence ( $\mathrm{fi}=\mathrm{Fi} / \mathrm{F} 1$, where $\mathrm{Fi}$ is fluorescence at cycle i) was calculated for all wells and kinetic readings, and area under the curve (AUC) were calculated for the 35 cycles as $\mathrm{AUC}=(\mathrm{f} 1+\mathrm{f} 35) / 2+(\mathrm{f} 2+\mathrm{f} 3 . . .+\mathrm{f} 33+\mathrm{f} 34)$. The net area under the curve (NAUC) was calculated as AUC sample AUC blank. ORAC value was then calculated as (NAUC sample/NAUC Trolox) x 40 and expressed as $\mu$ moles Trolox equivalents per gram of sample ( $\left.\mu \mathrm{molTE} \mathrm{g}^{-1}\right)$.

\section{Statistical analysis}

ANOVA was used to assess statistical differences among eggplant types with a 5\% confidence's level. When significance difference was found, Tukey's multiple range tests were carried out to separate means using MINITAB 14.0 (MINITAB, 2004). Data were expressed as means values of three samples \pm standard deviation.

\section{Results and discussion}

\section{Proximate composition}

In spite of its small fruits, Thai type showed the highest values in crude fibre, ashes and carbohydrates. Although Thai also showed the highest protein content it was only significantly higher than Chinese and as far as dietary fibre only Hindu had values close to Thai (Tab. 1). All eggplants had moisture content greater than $90 \%$, protein content lower than $1 \%$ and low fat with $0.04 \%$ (Tab. 1). Similar data were reported in different cultivars, with values ranging from 91.8 to $94.2 \%$ for moisture, 0.11 to $1.2 \%$ for protein and $0.3 \%$ to $0.7 \%$ for ash (on fresh weight basis) (Flick et al., 1978; Muñoz de Chavez et al., 1996; Maroto, 2002). Vegetables are characterized for the high content of fibre

Tab. 1. Proximate composition of eggplant types grown in Sinaloa, Mexico ( $\mathrm{g} 100 \mathrm{~g}^{-1}$ fresh weight)

\begin{tabular}{|c|c|c|c|c|c|}
\hline Component & Chinese & Philippine & American & Hindu & Thai \\
\hline Water & $92.50 \pm 0.11^{\mathrm{a}}$ & $92.60 \pm 0.09^{\mathrm{a}}$ & $92.70 \pm 0.08^{a}$ & $92.60 \pm 0.04^{a}$ & $90.10 \pm 0.25^{b}$ \\
\hline Crude fibre & $0.73 \pm 0.01^{b}$ & $0.78 \pm 0.01^{b}$ & $0.78 \pm 0.08^{b}$ & $0.65 \pm 0.02^{c}$ & $1.54 \pm 0.01^{\mathrm{a}}$ \\
\hline Ash & $0.69 \pm 0.05^{b}$ & $0.72 \pm 0.01^{\mathrm{b}}$ & $0.36 \pm 0.08^{c}$ & $0.48 \pm 0.02^{c}$ & $1.04 \pm 0.01^{\mathrm{a}}$ \\
\hline Protein & $0.65 \pm 0.06^{b}$ & $0.69 \pm 0.09^{\mathrm{ab}}$ & $0.67 \pm 0.13^{\mathrm{ab}}$ & $0.75 \pm 0.05^{\mathrm{ab}}$ & $0.90 \pm 0.07^{\mathrm{a}}$ \\
\hline Fat & $0.04 \pm 0.01^{\mathrm{a}}$ & $0.03 \pm 0.00^{\mathrm{a}}$ & $0.04 \pm 0.01^{\mathrm{a}}$ & $0.03 \pm 0.01^{\mathrm{a}}$ & $0.04 \pm 0.01^{\mathrm{a}}$ \\
\hline Carbohydrates $^{+}$ & $6.12 \pm 0.11^{\mathrm{bc}}$ & $5.96 \pm 0.06^{c}$ & $6.23 \pm 0.27^{b c}$ & $6.14 \pm 0.08^{b}$ & $7.92 \pm 0.37^{\mathrm{a}}$ \\
\hline Dietary fibre & $2.76 \pm 0.14^{\mathrm{b}}$ & $1.61 \pm 0.15^{c}$ & $2.63 \pm 0.18^{b}$ & $3.59 \pm 0.08^{a}$ & $3.93 \pm 0.15^{a}$ \\
\hline
\end{tabular}


541

and are considered as a primary source for humans. The highest content $(>3.5 \%)$ in dietary fibre found in Thai and Hindu was significantly different than the rest of the eggplant types. Sánchez-Castillo et al. (1999), analyzed the dietary fibre content in different vegetables grown in Mexico reporting a $2.4 \%$ values for eggplants, while a study carried out in Chile by Pak (2000), found 1.3\% in cooked eggplants without skin and seeds; Takeyama et al. (2002) reported a content of around $2.4 \%$ in a Japanese cultivar, and Rehman et al. (2003) found a value of $1.5 \%$ of dietary fibre in eggplants cultivated in Pakistan. An average intake of $25 \mathrm{~g} \mathrm{day}^{-1}$ of dietary fibre in adults is recommended by the American Dietetic Association (based on a $2000 \mathrm{kcal}^{\text {day }}{ }^{-1}$ diet) (Marlett et al., 2002). Based on this value, an intake of $100 \mathrm{~g} \mathrm{day}^{-1}$ of the eggplant types analyzed in this study could account for 6.5 to $16 \%$ of the recommended daily intake (RDI).

\section{Mineral content}

Tab. 2 provided results of mineral composition for the five eggplant types. Hindu had the highest values for $\mathrm{K}, \mathrm{Ca}$, and $\mathrm{Zn}$; along with American it has the highest concentrations of $\mathrm{P}, \mathrm{Mg}$ and $\mathrm{Mn}$. Philippine reported the highest Fe content, and no differences among the five types were found for $\mathrm{Cu}$ concentration. Although $\mathrm{Na}$ content varied widely, it was statistically the same for Hindu,
American and Chinese. Ekholm et al. (2007) found a similar pattern and mineral content in eggplants cultivated in Finland, as compared to our work, where $\mathrm{K}$ showed the highest concentration $\left(175 \mathrm{mg}^{100 \mathrm{~g}^{-1}}\right)$ and $\mathrm{Cu}$ showed the lowest result $\left(0.03 \mathrm{mg} 100 \mathrm{~g}^{-1}\right)$. On the other hand, a study carried out in eggplants grown in Saudi Arabia by Mohamed et al. (2003) showed a different mineral concentration $\left(\mathrm{mg} 100 \mathrm{~g}^{-1}\right)$ reporting 274 for $\mathrm{Ca}, 222$ for $\mathrm{Na}$ and 212 for $\mathrm{K}$. Those values are higher than those found in our study. Eggplants are a good source of biologically essential minerals like $\mathrm{K}, \mathrm{Ca}, \mathrm{Mg}, \mathrm{P}, \mathrm{Na}$ and $\mathrm{Fe}$; their contents are similar to those found in tomatoes and higher than those reported in carrots, potatoes and onions, which are the most common vegetables consumed in Mexico.

\section{Ascorbic acid (Vitamin C)}

The ascorbic acid content in eggplant types (Tab. 3) showed values ranging between 7.4 and $22 \mathrm{mg} 100 \mathrm{~g}^{-1}$ with Thai and Hindu with lower and highest content respectively. All of our results are higher than the $4 \mathrm{mg}$ ascorbic acid $100 \mathrm{~g}^{-1}$ reported in Spain (Esteban et al., 1992) and Turkey (Dürüst et al., 1997). Prohens et al. (2007) found $1.4,1.6$ and $1.8 \mathrm{mg}$ ascorbic acid $100 \mathrm{~g}^{-1}$ for a Thai ('Thai Round'), a Chinese ('Kermit') and a European ('Black Beauty') cultivars, respectively. On the other hand, Hanson et al. (2006) quantified ascorbic acid contents of

Tab. 2. Mineral content of eggplant types grown in Sinaloa, Mexico ( $\mathrm{mg}^{100 \mathrm{~g}^{-1}}$ fresh weight)

\begin{tabular}{|c|c|c|c|c|c|}
\hline Element & Chinese & Philippine & American & Hindu & Thai \\
\hline $\mathrm{K}$ & ${ }^{*} 151.21 \pm 17.93^{b}$ & $121.06 \pm 4.05^{\mathrm{c}}$ & $152.15 \pm 8.59^{\mathrm{ab}}$ & $191.18 \pm 1.49^{\mathrm{a}}$ & $176.46 \pm 6.11^{b}$ \\
\hline $\mathrm{Ca}$ & $28.00 \pm 0.77^{c}$ & $32.80 \pm 4.97^{c}$ & $31.36 \pm 1.06^{c}$ & $59.63 \pm 7.71^{a}$ & $45.08 \pm 1.14^{\mathrm{b}}$ \\
\hline $\mathrm{P}$ & $21.21 \pm 0.56^{\mathrm{b}}$ & $13.80 \pm 0.86^{\mathrm{c}}$ & $29.61 \pm 3.28^{a}$ & $33.52 \pm 1.34^{\mathrm{a}}$ & $30.42 \pm 1.25^{\mathrm{a}}$ \\
\hline $\mathrm{Mg}$ & $15.29 \pm 0.86^{c}$ & $15.74 \pm 0.95^{c}$ & $25.35 \pm 2.13^{\mathrm{a}}$ & $28.96 \pm 1.97^{a}$ & $20.88 \pm 1.17^{b}$ \\
\hline $\mathrm{Na}$ & $9.40 \pm 0.28^{a}$ & $5.76 \pm 0.65^{b}$ & $8.49 \pm 0.69^{a}$ & $11.54 \pm 2.65^{a}$ & $5.61 \pm 0.93^{b}$ \\
\hline $\mathrm{Fe}$ & $2.40 \pm 0.17^{b}$ & $3.13 \pm 0.32^{\mathrm{a}}$ & $0.86 \pm 0.05^{d}$ & $1.53 \pm 0.25^{c}$ & $1.80 \pm 0.26^{\mathrm{c}}$ \\
\hline $\mathrm{Zn}$ & $0.33 \pm 0.04^{\mathrm{d}}$ & $0.26 \pm 0.03^{\mathrm{d}}$ & $0.51 \pm 0.01^{\mathrm{b}}$ & $0.78 \pm 0.04^{\mathrm{a}}$ & $0.45 \pm 0.00^{c}$ \\
\hline $\mathrm{Mn}$ & $0.36 \pm 0.01^{b}$ & $0.30 \pm 0.02^{c}$ & $0.41 \pm 0.02^{\mathrm{ab}}$ & $0.44 \pm 0.02^{\mathrm{a}}$ & $0.39 \pm 0.01^{b}$ \\
\hline $\mathrm{Cu}$ & $0.15 \pm 0.02^{\mathrm{a}}$ & $0.13 \pm 0.03^{\mathrm{a}}$ & $0.15 \pm 0.01^{\mathrm{a}}$ & $0.15 \pm 0.01^{\mathrm{a}}$ & $0.18 \pm 0.03^{\mathrm{a}}$ \\
\hline Total & 228.35 & 192.98 & 248.89 & 327.73 & 281.27 \\
\hline
\end{tabular}

Mean values in a row with different letters are significantly different at $\mathrm{P} \leq 0.05$. Mean values of three samples \pm SD

Tab. 3. Nutraceutical components and antioxidant capacity of eggplant types grown in Sinaloa, Mexico

\begin{tabular}{|c|c|c|c|c|c|}
\hline Attribute & Chinese & Philippine & American & Hindu & Thai \\
\hline 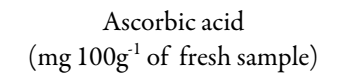 & ${ }^{*} 11.2 \pm 2.5^{\mathrm{b}}$ & $8.6 \pm 0.6^{b}$ & $8.9 \pm 2.2^{\mathrm{b}}$ & $22.0 \pm 4.1^{\mathrm{a}}$ & $7.4 \pm 2.9^{b}$ \\
\hline $\begin{array}{l}\text { Total soluble phenols } \\
\text { (mg CAE } 100 \mathrm{~g}^{-1} \text { of dry sample) }\end{array}$ & $1350.0 \pm 37.5^{\mathrm{d}}$ & $1562.7 \pm 57.3^{c}$ & $1512.5 \pm 21.7^{c}$ & $1750.0 \pm 43.3^{b}$ & $2049.8 \pm 77.8^{a}$ \\
\hline $\begin{array}{c}\text { Chlorogenic acid } \\
\text { (mg } 100 \mathrm{~g}^{-1} \text { of dry sample) }\end{array}$ & $953.3 \pm 47.3^{\mathrm{c}}$ & $916.7 \pm 45.1^{c}$ & $860.0 \pm 30.0^{c}$ & $1200.0 \pm 0.0^{\mathrm{b}}$ & $1700.0 \pm 100^{\mathrm{a}}$ \\
\hline Chlorogenic acid \%** & 70.61 & 58.66 & 56.87 & 68.57 & 82.93 \\
\hline Total anthocyanins ${ }^{* * *}$ & $128.7 \pm 1.5^{b}$ & $161.1 \pm 2.9^{\mathrm{a}}$ & $123.6 \pm 5.7^{b}$ & $82.8 \pm 2.6^{c}$ & $3.9 \pm 0.2^{d}$ \\
\hline ORAC $^{* * * *}$ & $296.2 \pm 16.7^{b}$ & $538.9 \pm 61.2^{\mathrm{a}}$ & $94.8 \pm 12.4^{c}$ & $352.1 \pm 24.5^{b}$ & $102.8 \pm 23.2^{c}$ \\
\hline $\mathrm{DPPH}^{* * * * *}$ & $56.1 \pm 3.3^{c}$ & $92.5 \pm 0.3^{\mathrm{a}}$ & $78.5 \pm 2.9^{\mathrm{b}}$ & $82.1 \pm 4.1^{\mathrm{ab}}$ & $77.8 \pm 7.8^{\mathrm{b}}$ \\
\hline $\mathrm{IC}_{50}(\mathrm{DPPH}, \mu \mathrm{g})$ & 0.0067 & 0.0033 & 0.0092 & 0.0039 & 0.0046 \\
\hline
\end{tabular}

Mean values in a row with different letters are significantly different at $\mathrm{P}<0.05,{ }^{*}$ Mean values of three samples $\pm \mathrm{SD}$,

${ }^{* *} \%$ Chlorogenic acid $=\left(\right.$ chlorogenic acid/total phenols)X100, ${ }^{* * *} \mathrm{mgC}_{3} \mathrm{GE} 100 \mathrm{~g}^{-1},{ }^{* * *} \mu$ molTE $\mathrm{g}^{-1}$ dry basis, ${ }^{* * * *} \%$ Inhibition of DPPH 


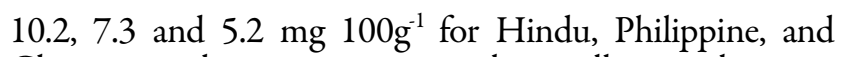
Chinese eggplant types respectively, in all cases the same types show higher values in our trial. To put consumption in perspective, Young (1999) suggested a recommended daily intake (RDI) of vitamin C in the range from 60 to 100 $\mathrm{mg}$. Eggplant consumptions of $100 \mathrm{~g} \mathrm{day}^{-1}$ as analyzed in this study, will account for 7 to $22 \%$ of the RDI.

\section{Total solublephenols}

Total soluble phenols in our work (Tab. 3) ranged from 1350 to $2049 \mathrm{mg} \mathrm{CAE} 100 \mathrm{~g}^{-1}$ in Chinese and Hindu, respectively a significant gradient was found among the rest of the eggplant types. Our results were higher than those reported by Raigón et al. (2008), their report was based on a study of $31 \mathrm{~S}$. melongena cultivars from around the world with total phenolic content ranged from 545 to $1048 \mathrm{mg}$ CAE $100 \mathrm{~g}^{-1}$, Ninfalli et al. (2005) also reported 820 and 925 mg CAE $100 \mathrm{~g}^{-1}$ for 'Black Beauty' and 'Violetta Lunga' varieties. Using five $S$. melongena cultivars of varied colours, Akanitapichat et al. (2010) reported values from 739 to $1116 \mathrm{mg}$ GAE $100 \mathrm{~g}^{-1}$, and Hanson et al. (2006) found values from 740 to $1430 \mathrm{mg} \mathrm{GAE} 100 \mathrm{~g}^{-1}$ in cultivars from around the world. In the other hand, a study by Okmen $e t$ al. (2009) showed contents from 878 to $1984 \mathrm{mg}$ GAE $100 \mathrm{~g}^{-1}$ in 26 Turkish cultivars, such data covered the whole range found in our study, except for the highest value we found in Thai.

\section{Chlorogenic acid}

Chlorogenic acid is one of the most ubiquitous phenolic acid in plants, particularly in the solanaceas (Clifford, 1999; Niggeweg et al., 2004). It has been reported that following consumption it is absorbed and metabolized by humans having a beneficial effect on health (Olthof et al, 2001; Olthof et al., 2003). The chlorogenic acid content found in

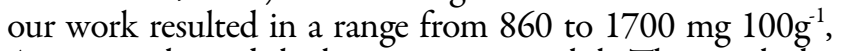
American showed the lowest amount, while Thai reach the highest value. Winter and Herrmann (1986) reported 902 and $821 \mathrm{mg} 100 \mathrm{~g}^{-1}$ of chlorogenic acid for Italian and Spanish eggplant cultivars, respectively. Comparing with our data, these results are similar to the ones reported for Philippine and American, respectively. Papanga et al. (1999) and Whitaker and Stommel (2003) found 947 and $960 \mathrm{mg}$ $100 \mathrm{~g}^{-1}$ of chlorogenic acid in eggplant flesh, respectively, which is similar to our data for Chinese. In the other hand, Mattila and Hellström (2007) reported a chlorogenic acid content of $492 \mathrm{mg} 100 \mathrm{~g}^{-1}$ in an eggplant cultivated in Finland and Singh et al. (2009) found a chlorogenic acid

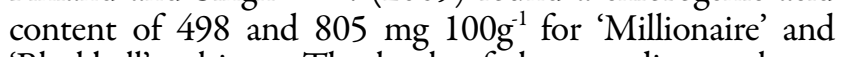
'Blackbell' cultivars. The levels of these studies are lower than all the eggplant types analyzed in our work. Several studies related to phenolic acids determination in eggplants, concluded that chlorogenic acid is the main phenolic acid in the flesh of this vegetable, but none of them, have reported it in terms of percentage as compared to the total phenols content. Analyzing data from total phenols and chlorogenic acid shows that chlorogenic acid represents more than 56\% of total phenols in all analyzed eggplant types (Tab. 3). Data variation in eggplant total phenols and chlorogenic acid among different reports is mainly attributed to solvent and extraction techniques used for extraction of phenolic compounds and such topic is analyzed by Luthria and Mukhopadhyay (2006).

\section{Anthocyanins}

Among the purple eggplant types, the highest amount of anthocyanins was observed in Philippine with $161 \mathrm{mgC}_{3} \mathrm{GE}$ $100 \mathrm{~g}^{-1}$, which coincides with the results for ORAC and DPPH antioxidant activity, while the lowest result was found in Hindu with $83 \mathrm{mg} \mathrm{C}_{3} \mathrm{GE} 100 \mathrm{~g}^{-1}$ (Tab. 3). No statistical differences between Chinese and American were found with 129 and $124 \mathrm{mg} \mathrm{C}_{3} \mathrm{G} 100 \mathrm{~g}^{-1}$, respectively. Anthocyanins data obtained in this study of purple fruits are higher than those reported by Papanga et al. (1999) and

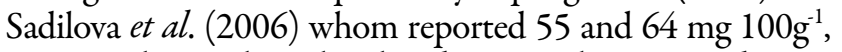
respectively. In the other hand, our anthocyanins data in Hindu and American are similar to those reported by Lo Scalzo et al. (2010) and Koponen et al. (2007) who

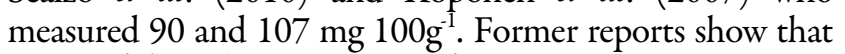
Bor et al. (2006) sampled S. melongena at retails in Taiwan, while Wu et al. (2006) in a comprehensive sample at 12 cities around the U.S. reported anthocyanin content values ranging from 167 and $1067 \mathrm{mg} 100 \mathrm{~g}^{-1}$ in commercial eggplants at retail points, which is higher than the amounts found in our five types study. All of these anthocyanin comparative studies used delphinidin or delphinidin derivatives as standard compounds for analysis.

Antioxidant capacity: DPPH radical scavenging activity and ORAC

Antioxidant activity was evaluated using DPPH and AAPH free radicals. AAPH free radical was used in the ORAC assay and results were expressed as $\mu$ moles Trolox equivalents per gram of sample $\left(\mu\right.$ molTE $\left.\mathrm{g}^{-1}\right)$, showing significant differences $(\mathrm{P} \leq 0.05)$ among the five types (Tab. 3). Results ranged from 95 to $539 \mu$ molTE $\mathrm{g}^{-1}$, with American and Philippine at each extreme. Thai samples $\left(103 \mu \mathrm{molTE} \mathrm{g}^{-1}\right)$ had no significant differences as compared to the American type, while Hindu and Chinese samples showed no significant differences with 296 and $352 \mu$ molTE $\mathrm{g}^{-1}$, each. IC 50 is defined as the amount of antioxidant material required to scavenge $50 \%$ of free radical in the assay system. Its value are inversely proportional to the antioxidant activity, the smaller the number the highest the scavenging activity. All eggplant types ranged from $\mathrm{IC}_{50}$ values of 0.0033 to 0.0092 . According to these, Philippine had the highest antioxidant activity with an $\mathrm{IC}_{50}$ of $0.0033 \mu \mathrm{g}$, while American has the lowest with only $0.0092 \mu \mathrm{g}$. Methodological similarities among the ORAC and $\mathrm{DPPH}$ methods may be due to the presence and specificity of the diverse bioactive molecules found in the evaluated eggplant types.

\section{Conclusions}

The five evaluated eggplant types specially Hindu and Thai, have significant content of some human promoting health components, such as crude and dietary fibre, as well as biologically essential minerals like $\mathrm{K}, \mathrm{Ca}, \mathrm{Mg}, \mathrm{P}, \mathrm{Na}$ and $\mathrm{Fe}$. They also provide important amounts of antioxidants like ascorbic acid and soluble phenolic compounds (mainly chlorogenic acid), as well as significant antioxidant. 
543

\section{Acknowledgments}

Authors would like to acknowledge the scholarship awarded to Guillermo Niño-Medina by CONACYT (Consejo Nacional de Ciencia y Tecnología) and the laboratory assistance by Laura Contreras-Angulo, Rosalba Contreras-Martínez, Verónica Pérez-Rubio and Werner Rubio-Carrasco.

\section{References}

Abdel-Aal ES, Hucl P (1999). A rapid method for quantifying total anthocyanins in blue aleurone and purple pericarp wheats. Cereal Chem 76(3):350-354.

Akanitapichat P, Phraibung K, Nuchklang K, Prompitakkul S (2010). Antioxidant and hepatoprotective activities of five eggplant varieties. Food Chem Toxicol 48(10):3017-3021.

AOAC (1998). Official Methods of Analysis. Association of Official Analytical Chemist. Maryland, AOAC International.

Bor J, Chen H, Yen G (2006). Evaluation of antioxidant activity and inhibitory effect on nitric oxide production of some common vegetables. J Agr Food Chem 54(5):1680-1686.

Cao G, Sofic E and Prior RL (1996). Antioxidant capacity of tea and common vegetables. J Agr Food Chem 44(11):34263431.

Chun OK, Kim DO (2004). Consideration on equivalent chemicals in total phenolic assay of chlorogenic acid-rich plums. Food Res Int 37(4):337-342.

Clifford MN (1999). Chlorogenic acids and other cinnamatesnature, occurrence and dietary burden. J Sci Food Agr $79(3): 362-372$.

Doner LW, Hicks KB (1981). High-performance liquid chromatographic separation of ascorbic acid, erythorbic acid, dehydroascorbic acid, dehydroerythorbic acid and diketogluconic acid. Anal Biochem 115(1):225-230.

Dürüst N, Sümengen D, Dürüst Y (1997). Ascorbic acid and element contents of foods of Trabzon (Turkey). J Agr Food Chem 45(6):2085-2087.

Ekholm P, Reinivuo H, Mattila P, Pakkala H, Koponen J, Happonen A, Hellström J, Ovaskainen ML (2007). Changes in the mineral and trace element contents of cereals, fruits and vegetables in Finland. J Food Compos Anal 20(6):487-495.

Esteban RM, Mollá EM, Robredo FJ, López-Andréu FJ (1992). Changes in the chemical composition of eggplant fruits during development and ripening. J Agr Food Chem 40(6):9981000.

Flick GJ, Burrnette FS, Aung LH, Ory RL, St Angelo AJ (1978). Chemical composition and biochemical properties of mirlitons (Sechium edule) and purple, green and white eggplants (Solanum melongena). J Agr Food Chem 26(5):1000-1005.

Hanson PM, Yang RY, Tsou SC, Ledesma D, Engle L, Lee TC (2006). Diversity in eggplant (Solanum melongena) for superoxide scavenging activity, total phenolics and ascorbic acid. J Food Compos Anal 19(6-7):594-600.
Heredia JB, Cisneros-Zevallos L (2009). The effects of exogenous ethylene and methyl jasmonate on the accumulation of phenolic antioxidants in selected whole and wounded fresh produce. Food Chem 115(4):1500-1508.

Huang D, Ou B, Hampsch-Woodil M, Flanagan J, Prior RL (2002). High-throughput assay of oxygen radical absorbance capacity (ORAC) using a multichannel liquid handling system coupled with a microplate fluorescence reader in 96-well format. J Agr Food Chem 50(16):4437-4444.

Kantharajah AS, Golegaonkar PG (2004). Somatic embryogenesis in eggplant. Sci Hortic-Amsterdam 99(2):107-117.

Kashyap V, Kumar SV, Collonnier C, Fusari F, Haicour R, Rotino GL, Sihachakr D, Rajam MV (2003). Biotechnology of eggplant. Sci Hortic-Amsterdam 97(1):1-25.

Koponen JM, Happonen AM, Mattila PH, Törrönen R (2007). Contents of anthocyanins and ellagitannins in selected foods consumed in Finland. J Agr Food Chem 55(4):1612-1619.

Lo Scalzo R, Fibiani M, Mennella G, Rotino GL, Dal Sasso M, Culici M, Spallino A, Braga PC (2010). Thermal treatment of eggplant (Solanum melongena L.) increases the antioxidant content and the inhibitory effect on human neutrophil burst. J Agr Food Chem 58(6):3371-3379.

Luthria DL, Mukhopadhyay S (2006). Influence of sample preparation on assay of phenolic acids from eggplant. J Agr Food Chem 54(1):41-47.

Manach C, Scalbert A, Morand C, Rémésy C, Jiménez L (2004). Polyphenols: food sources and bioavailability. Am J Clin Nutr 79(5):727-747.

Marlett JA, McBurney MI, Slavin JL (2002). Position on the American dietetic association: health implications of dietary fiber. J Am Diet Assoc 102(7):993-100.

Maroto JV (2002). Horticultura Herbácea Especial. $5^{\text {th }}$ Ed. Ediciones Mundi-Prensa. Mexico. pp. 481-495 p.

Mattila P, Hellström J (2007). Phenolic acids in potatoes, vegetables and some of their products. J Food Compos Anal 20(3-4):152-160.

MINITAB (2004). Statistical software. Release number 14. www.minitab.com.

Mohamed AE, Rashed MN, Mofty A (2003). Assessment of essential and toxic elements in some kinds of vegetables. Ecotox Environ Safe 55(3):251-60.

Muñoz de Chávez M, Chávez A, Roldán J, Ledesma J, Mendoza E, Pérez-Gil F (1996). Tablas de valor nutritivo de los alimentos de mayor consumo en Mexico. $2^{\text {nd }}$ Ed. Editorial Pax. Mexico, $54 \mathrm{p}$.

Ninfalli VP, Mea G, Giorgini S, Rocchi M, Bacchiocca M (2005). Antioxidant capacity of vegetables, spices and dressings relevant to nutrition. Brit J Nutr 93(2):257-266.

Niggeweg R, Michael AJ, Martin C (2004). Engineering plants with increased levels of the antioxidant chlorogenic acid. Nat Biotechnol 22(6):746-754.

Noda Y, Kneyuki T, Igarashi K, Mori A, Packer L (2000). Antioxidant activity of nasunin, an anthocyanin in eggplant peels. Toxicology 148(2-3):119-123. 
Okmen B, Sigva HO, Mutlu S, Doganlar S, Yemenicioglu A, Frary A (2009). Total antioxidant activity and total phenolic contents in different Turkish eggplant (Solanum melongena L.) cultivars. Int J Food Prop 12(3):616-624.

Olthof MR, Hollman PC, Katan MB (2001). Chlorogenic acid and caffeic acid are absorbed in humans. J Nutr 131(1):66-71.

Olthof MR, Hollman PC, Buijsman NC, Van Amelsvoort JM, Katan MB (2003). Chlorogenic acid, quercetin-3-rutinoside and black tea phenols are extensively metabolized in humans. J Nutr 133(6):1806-1814.

Özgür MÜ, Sungur S (1995). Third order derivative spectrophotometric determination of ascorbic acid in fruits and vegetables. Talanta 42(11):1631-1640.

Pak DN (2000). Fibra dietética en verduras cultivadas en Chile. Arch Latinoam Nutr 50(1):97-101.

Papanga G, Miller N, Rice-Evans CA (1999). The polyphenolic content of fruit and vegetables and their antioxidant activities. What does a serving constitute? Free Radical Res 30(2):153162.

Prior RL, Hoang H, Gu L, Wu X, Bacchiocca M, Howard L, Hampsch-Woodill M, Huang D, Ou B, Jacob R (2003). Assays for hydrophilic and lipophilic antioxidant capacity (oxygen radical absorbance capacity $\left(\mathrm{ORAC}_{\mathrm{FL}}\right)$ ) of plasma and other biological and food samples. J Agr Food Chem 51(11):3273-3279.

Prohens J, Rodríguez-Burruezo A, Raigón MD, Nuez F (2007). Total phenolic concentration and browning susceptibility in a collection of different varietal types and hybrids of eggplant: implications for breeding for higher nutritional quality and reduced browning. J Am Soc Hortic Sci 132(5):638-646.

Raigón MD, Prohens J, Muñoz-Falcón JE, Nuez F (2008). Comparison of eggplant landraces and commercial varieties for fruit content of phenolics, minerals, dry matter and protein. J Food Compos Anal 21(5):370-376.
Rehman ZU, Islam M, Shah WH (2003). Effect of microwave and conventional cooking on insoluble dietary fibre components of vegetables. Food Chem 80(2):237-40.

Sadilova E, Stintzing FC, Carle R (2006). Anthocyanins, colour and antioxidant properties of eggplant (Solanum melongena L.) and violet pepper (Capsicum annuum L.) peel extracts. Z Naturforsch C 61(7-8):527-535.

Sánchez-Castillo CP, Englyst HN, Hudson GJ, Lara JJ, Solano ML, Munguía JL, James WP (1999). The non-starch polysaccharide content of Mexican foods. J Food Compos Anal 12(4):293-314.

Scalbert A, Williamson G (2000). Dietary intake and bioavailability of polyphenols. J Nutr 130(8):2073S-2085S.

Singh AP, Luthria D, Wilson T, Vorsa N, Singh V, Banuelos GS, Pasakdee S (2009). Polyphenols content and antioxidant capacity of eggplant pulp. Food Chem 114(3):955-961.

Takeyama E, Fukushima M, Tanimura A (2002). Effect of heattreatment on the content and polysaccharide composition of dietary fiber. Food Sci Technol Res 8(2):125-130.

United States Department of Agriculture (USDA) (2014). USDA National Nutrient Database for Standard Reference. http://www.nal.usda.gov/fnic/foodcomp/search.

Whitaker BD, Stommel JR (2003). Distribution of hydroxycinnamic acid conjugates in fruit of eggplant (Solanum melongena L.) cultivars. J Agr Food Chem 51(11):3448-3454.

Winter M, Herrmann K (1986). Esters and glucosides of hydroxycinnamic acids in vegetables. $\mathrm{J}$ Agr Food Chem 34(4):616-620.

Wu X, Beecher GB, Holden JM, Haytowitz DB, Gebhardt SE, Prior RL (2006). Concentrations of anthocyanins in common foods in the United States and estimation of normal consumption. J Agr Food Chem 54(11):4069-4075.

Young M (1999). How much vitamin C do you need?. JAMA-J Am Med Assoc 281(15):1460. 